\title{
Examining the Correlation Between Depression and Social Behavior on Smartphones Through Usage Metadata: Empirical Study
}

Yameng Wang ${ }^{1,2}$, MSc; Xiaotong Ren ${ }^{3}$, BA; Xiaoqian Liu ${ }^{1,4}, \mathrm{PhD}$; Tingshao Zhu ${ }^{1,4}$, Prof Dr

${ }^{1}$ CAS Key Laboratory of Behavioral Science, Institute of Psychology, Chinese Academy of Sciences, Beijing, China

${ }^{2}$ School of Computer Science and Technology, University of Chinese Academy of Sciences, Beijing, China

${ }^{3}$ College of Foreign Languages, Capital Normal University, Beijing, China

${ }^{4}$ Department of Psychology, University of Chinese Academy of Sciences, Beijing, China

Corresponding Author:

Tingshao Zhu, Prof Dr

CAS Key Laboratory of Behavioral Science

Institute of Psychology

Chinese Academy of Sciences

16 Lincui Road, Chaoyang District

Beijing, 100101

China

Phone: 8615010965509

Email: tszhu@psych.ac.cn

\section{Abstract}

Background: As smartphone has been widely used, understanding how depression correlates with social behavior on smartphones can be beneficial for early diagnosis of depression. An enormous amount of research relied on self-report questionnaires, which is not objective. Only recently the increased availability of rich data about human behavior in digital space has provided new perspectives for the investigation of individual differences.

Objective: The objective of this study was to explore depressed Chinese individuals' social behavior in digital space through metadata collected via smartphones.

Methods: A total of 120 participants were recruited to carry a smartphone with a metadata collection app (MobileSens). At the end of metadata collection, they were instructed to complete the Center for Epidemiological Studies-Depression Scale (CES-D). We then separated participants into nondepressed and depressed groups based on their scores on CES-D. From the metadata of smartphone usage, we extracted 44 features, including traditional social behaviors such as making calls and sending SMS text messages, and the usage of social apps (eg, WeChat and Sina Weibo, 2 popular social apps in China). The 2-way ANOVA (nondepressed vs depressed $\times$ male vs female) and multiple logistic regression analysis were conducted to investigate differences in social behaviors on smartphones among users.

Results: The results found depressed users received less calls from contacts (all day: $F_{1,116}=3.995, P=.048, \eta_{2}=0.033$; afternoon: $F_{1,116}=5.278, P=.02, \eta_{2}=0.044$ ), and used social apps more frequently (all day: $F_{1,116}=6.801, P=.01, \eta_{2}=0.055$; evening: $F_{1,116}=6.902$, $P=.01, \eta_{2}=0.056$ ) than nondepressed ones. In the depressed group, females used Weibo more frequently than males (all day: $F_{1,116}=11.744, P=.001, \eta_{2}=0.092$; morning: $F_{1,116}=9.105, P=.003, \eta_{2}=0.073$; afternoon: $F_{1,116}=14.224, P<.001, \eta_{2}=0.109$; evening: $\left.F_{1,116}=9.052, P=.003, \eta_{2}=0.072\right)$. Moreover, usage of social apps in the evening emerged as a predictor of depressive symptoms for all participants (odds ratio [OR] 1.007, 95\% CI 1.001-1.013; $P=.02$ ) and male (OR 1.013, 95\% CI 1.003-1.022; $P=.01$ ), and usage of Weibo in the morning emerged as a predictor for female (OR 1.183, 95\% CI 1.015-1.378; $P=.03$ ).

Conclusions: This paper finds that there exists a certain correlation between depression and social behavior on smartphones. The result may be useful to improve social interaction for depressed individuals in the daily lives and may be insightful for early diagnosis of depression.

(JMIR Mhealth Uhealth 2021;9(1):e19046) doi: $\underline{10.2196 / 19046}$ 


\section{KEYWORDS}

depression; digital phenotyping; social behavior; smartphone usage; mobile sensing

\section{Introduction}

Depression is a mental disorder that is widespread in the world, with more than 300 million people affected [1]. Subthreshold depressive symptoms are far more common, causing significant impairment in people's lives and putting them at risk for future mental health concerns [2]. Depression is not only associated with decreased quality of life [3], decreased work productivity [4], and physical illnesses such as cardiovascular problems [5] and Alzheimer disease [6], but also increases the mortality and suicide rate $[7,8]$. The World Health Organization estimates that depression will be the leading cause of disease burden by 2030 [9].

Although depression is treatable using different methods, including antidepressants and psychotherapy, only fewer than half of those eligible received treatment [10,11]. One of the main obstacles is the difficulty of diagnosing depression. For instance, guideline-concordant care for depressed patients seeking treatment is typically initiated by primary care physicians [12,13], whereas primary care physicians might fail to identify most patients with depressive symptoms $[14,15]$. Because early treatment and intervention are shown to be associated with a better prognosis [16], more efficient methods of identifying depression could significantly improve the delivery of services to those in need.

Currently, smartphone has led to an enormous increase in personal convenience and effectiveness, with more than 3 billion users worldwide [17]. Despite the many uses and advantages of smartphones, they also bring many negative effects on the mental health of individuals (eg, depression). There has been evidence that general and problematic smartphone usage commonly co-occur with depression. On the one hand, some studies found that depression can cause smartphone addiction, because depressed individuals take their smartphones as a coping method to deal with their depressive emotion [18,19]. On the other hand, some studies found that high smartphone usage is associated with subsequent stress, sleep diculties, and depression [20,21]. Furthermore, some studies found a bidirectional relationship between smartphone usage and depression [22]. Specifically, depressed individuals may be driven to excessively use their smartphone to get rid of negative emotions, but this excessive smartphone usage consequently elicits more sleep problems, depression, irritability, and stress.

Communication and interpersonal interaction are among the most important functions of smartphones, and much research has been conducted on the relationship between depression and social behaviors on smartphones. While a smartphone is essential for communication and interpersonal interaction, it may make people less engaged with their real-life social environment [23-25]. Several studies found that depressed users have been reported to make fewer calls, but send more SMS text messages [26-28]. Kim et al [22] found that depressed users may rely on smartphones to alleviate their negative feelings and spend more time on communication, which in turn can deteriorate into problematic outcomes. Tamura et al [29] found that smartphone usage of 2 hours or more per day for social network services and online chats is associated with a higher risk of depression.

However, the majority of relevant studies measured smartphone usage using a self-report methodology. And self-reported smartphone usage did not correlate robustly with objectively measured smartphone usage [30,31]. Only recently, the increased availability of smartphone-based passive sensing data has provided new perspectives for the investigation of physical, individual differences, or mental health [32-34]. For instance, Saeb et al [35] found that both smartphone usage duration and frequency are positively associated with depression by analyzing daily life behavioral markers obtained using smartphone GPS and usage sensors. Using a smartphone-based self-monitoring system, Faurholt et al [36] found that depressive state in patients with bipolar disorder was related to more screen time, while manic state was related to frequent smartphone usage. Furthermore, it has been demonstrated that behavior data collected via smartphone can be used for monitoring individual depressive states [37], detecting social rhythms in bipolar disorder [38], and mobile intervention for depression [39]. Therefore, we aim to conduct research on depressed users' social behavior in digital space through metadata collected via smartphones.

To gain deeper insights, we include a broad range of behaviors based on previous studies which have reported on behavioral manifestations of depression in various types of behavior. For example, traditional communication behaviors (eg, making calls, sending SMS text messages) have been shown to be associated with depressive symptoms in many studies $[23,27,28]$. Moreover, as Baker et al [40] reviewed, there is a complex relationship between online social networking and depressive symptoms. Given that $99.1 \%$ of internet users are mobile internet users in China [41], usage of social apps on smartphones may be also associated with depression.

In addition, gender differences exist not only in depression but also in smartphone usage. Specifically, males with depression show impairment at lower symptom levels than females [42], and report consistently fewer symptoms than females [43]. As for gender differences in smartphone usage, several studies found that female users' smartphone usage is typically related to sociability, interpersonal relationships, and the creation of new relationships [44,45], but for male users, smartphone usage is simultaneously based on SMS text messages and voice conversations $[46,47]$. Furthermore, virtually all the studies indicate that females have higher levels of dependence and problematic usage than males [48,49]. Therefore, gender differences may also exist in the social behaviors on smartphones of depressed users.

By analyzing smartphone usage, this paper aims to examine the correlation between depression and social behavior on smartphones through metadata collected via smartphones. Specifically, we hypothesized that nondepressed and depressed 
users may have differences in social behaviors on smartphones, and there are gender differences in social behavior among depressed users.

\section{Methods}

\section{Study Procedure}

In this study, a 2-step procedure was conducted: (1) data collection and (2) data analysis. In order to collect metadata of smartphone usage automatically, we developed an Android app named MobileSens [50,51]. MobileSens consists of 2 modules, one is for collecting metadata of smartphone usage, and the other is for filling the questionnaire, which can get smartphone usage data and the corresponding questionnaire results at the same time.

\section{Data Collection}

\section{Participants}

We recruited participants in Beijing, China, who own Android smartphones and also use smartphones in daily life by advertising on social networks. During this study, all participants were instructed to install MobileSens on their smartphones, and use it for more than 1 month. Given psychological measurement scales are composed of retrospective questions, participants were asked to fill out the corresponding questionnaires on the last day of metadata collection to ensure consistency between metadata and participants' psychological state. To encourage participants to take part in our study, we offered them a monetary reward depending on the number of days the smartphone usage data was uploaded. In particular, if participants finished uploading 30 days' data and completed the questionnaires, we rewarded them with RMB 200 (US \$30). However, if participants dropped out of the study after finishing questionnaires and uploading data for less than 30 days, we provided experimental rewards based on the number of days the data were uploaded. This study was approved by the Review Board of Institute of Psychology, Chinese Academy of Sciences, H09036. Signed informed consent was obtained from each participant. Finally, we acquired data from a total of 120 participants (73 males, 47 females) with a mean age of 23.57 (SD 3.09).

\section{Metadata of Smartphone Usage}

MobileSens ran in the background to collect designated metadata. After participants installed MobileSens into their smartphone, most of their interactions with the smartphone were recorded and no sensitive personal data, such as the specific content of the SMS text messages, were collected. This app sensed a total of 15 categories of smartphone interaction events, as listed in Table 1. All the data would be uploaded via the internet to a remote central data server.

Table 1. Details on smartphone log data.

\begin{tabular}{ll}
\hline Category & Record content \\
\hline App activity log & App creation/resume/launch/stop/exit \\
App package log & $\begin{array}{c}\text { App package uninstallation/installation/replacement/change/data } \\
\text { cleanup/restart }\end{array}$ \\
Call log & Number, contact name, and direction of call \\
Camera log & Use of camera button \\
Contact log & Contacts addition/deletion \\
Date change log & Change system date and time \\
GPS log & User's locale, altitude, latitude, longitude, and direction of movement \\
Headset log & Plug in/off headset \\
Location changed log & Change location \\
Power connected log & Connect/disconnect the power \\
Power log & Power on/off \\
Screen log & Screen on/off \\
Service app log & Service app creation/resume/launch/stop/exit \\
SMS text message log & Number, contact name, and direction of SMS text message \\
Wallpaper log & Change wallpaper \\
\hline
\end{tabular}

\section{Questionnaires}

On the last day of the study, each participant was required to complete an online assessment using MobileSens, consisting of a demographic questionnaire and a depression measurement scale. Depressive symptoms (minor depression) were evaluated using the Center for Epidemiological Studies-Depression Scale (CES-D) [52], which is widely used to measure depressive

symptoms severity in the general population and is applicable to different ethnic contexts [53]. The CES-D measures the frequency of 20 depressive symptoms over the past week on a 4-point Likert scale. The total score may range from 0 to 60 , with higher scores indicating higher levels of depression. In this study the Chinese version of questionnaire was implemented, and their validity and reliability have been proved previously [54]. 


\section{Data Analysis}

\section{Feature Extraction}

Among the metadata of smartphone usage sensed by MobileSens, the analyses of this work focused on call log, SMS text message log, and app activity log. These metadata are directly or, in some cases, indirectly related to individuals' social behavior on smartphones. For instance, call log and SMS text message log are the direct output of individuals' communication behavior; app activity log belonging to social apps can reflect individuals' online social activities, although social apps also have entertainment and information acquisition functions. Specifically, we designed 2 categories of social behaviors on metadata:

\section{Traditional Communication Behavior}

We mainly focused on the frequency of usage of calls and SMS text messages. In particular, we designed 4 kinds of behaviors related to traditional communication behavior from the metadata (making calls, receiving calls, sending SMS text messages, and receiving SMS text messages). In order to analyze the communication behavior between individuals and acquaintances (eg, contacts on smartphones), we designed another 4 kinds of communication behaviors that occur between contacts, which included making calls to contacts, receiving calls from contacts, sending SMS text messages to contacts, and receiving SMS text messages from contacts. Finally, we obtained a total of 8 behaviors.

\section{Usage of Social Apps}

We analyzed the frequency of usage of social apps from the following 2 aspects. First, we analyzed the frequency of usage of all social apps. Specifically, using a web crawler, we crawled an app classification framework from the Wandoujia app store (one of the most popular Android app stores in China), and got a list of all the social apps. Then, we extracted from metadata the usage records of all social apps for social apps' usage behavior. Second, we analyzed the frequency of usage of WeChat and Sina Weibo, 2 popular social apps in China, respectively. Finally, we designed a total of 3 behaviors.

After designing the above 2 categories of social behaviors, we extracted features from each category of behavior. Specifically, after calculating the frequency of all behaviors per day for each participant, we used the mean of the frequency of these behaviors as the feature of social behavior on smartphone all day (0:00 to 24:00). In addition, social activity represents the most important factor disrupting circadian rhythms after alternation of light/dark cycle [55], meaning that individuals' social behavior may differ between day and night. Moreover, circadian rhythms have repeatedly been linked to individual depression [56,57]. Thus, it may make sense to analyze individuals' social behaviors on smartphones during the day and at night. Further, some studies have found that many people with depression show a regular daily pattern of symptoms, usually with more severe symptoms in the morning $[58,59]$. To explore this difference, after dividing a day into day and night, we divided the day into morning and afternoon (morning: 6:00 to 12:00; afternoon: $12: 00$ to 18:00; evening: $18: 00$ to $6: 00$ ). And then we calculated the average frequency of smartphone social behavior in different periods as the final features. Finally, we extracted a total of $(8+3) \times(1+3)=44$ behavior features.

\section{Depressive Symptoms}

To examine differences in social behaviors on smartphones between depressed and nondepressed users, we divided participants into 2 groups based on their scores on CES-D. The score of 16 has been traditionally used as a cutoff point for determining whether a person has symptoms of depression not only in Western countries [60], but also in China [54]. In this study, the cutoff point of 16 was used to distinguish individuals considered to be depressive from those classified as nondepressed.

\section{Statistical Analysis}

Descriptive statistics were computed as the mean and SD for continuous variables and absolute frequencies and percentage for categorical variables. The chi-square test and independent $t$-test were used to compare demographics between 2 groups. The 2-way ANOVA of depressive symptom (nondepressed group vs depressed group) $\times$ gender (male vs female) was conducted to examine the differences in social behaviors. Multiple logistic regression analysis with dichotomous depressive symptoms (nondepressed vs depressed) as dependent variables was used to find predictors of depressive symptoms. In this analysis, variable selection was performed using stepwise forward selection, subsequently including one by one the variables that were not statistically significant $(\alpha=.05)$. To improve the chances of retaining meaningful predictor variables, demographics that differed between the groups at $P<.1$, and behavior features that differed in the main effect of depressive symptoms in 2-way ANOVA at $P<.1$ were analyzed as independent variables via multiple logistic regression analysis [61]. For further data exploration of gender differences, multiple logistic regression models adjusted for gender were conducted. All statistical tests were performed using SPSS version 23 for Windows (IBM). The level of significance was set at .05.

\section{Results}

\section{Demographics and Questionnaire Scores of CES-D}

Of the 120 participants who formed the study sample, 71 participants were divided into the nondepressed group and 49 participants were divided into the depressed group. Demographics of participants are summarized in Table 2. The results of the chi-square test and independent $t$-test on demographics between the nondepressed and depressed groups showed no significance (gender: $P=.76$; education: $P=.34$; living place: $P=.99$; occupation: $P=.75$; marital status: $P=.36$; and age: $P=.31)$. 
Table 2. Demographics of participant versus depressive symptoms.

\begin{tabular}{|c|c|c|c|c|}
\hline Characteristic & Nondepressed group $(\mathrm{N}=71)$ & Depressed group $(\mathrm{N}=49)$ & $\chi^{2}(d f)$ or $t(d f)$ & $P$-value \\
\hline Gender, n (\%) & & & $0.10(1)$ & $.76^{\mathrm{a}}$ \\
\hline Male & $27(38)$ & $20(41)$ & & \\
\hline Female & $44(62)$ & $29(59)$ & & \\
\hline Education, $\mathbf{n}(\%)$ & & & $2.16(2)$ & $.34^{\mathrm{a}}$ \\
\hline Below university diploma & $3(4)$ & $0(0)$ & & \\
\hline University diploma & $28(39)$ & $21(43)$ & & \\
\hline Above university diploma & $40(56)$ & $28(57)$ & & \\
\hline Living place, $n(\%)$ & & & $0.02(2)$ & $.99^{\mathrm{a}}$ \\
\hline City & $37(52)$ & $26(53)$ & & \\
\hline Town & $13(18)$ & $9(18)$ & & \\
\hline Country & $21(30)$ & $14(29)$ & & \\
\hline Occupation, n (\%) & & & $0.10(1)$ & $.75^{\mathrm{a}}$ \\
\hline Student & $64(90)$ & $45(92)$ & & \\
\hline Others & $7(10)$ & $4(8)$ & & \\
\hline Marital status, n (\%) & & & $0.83(1)$ & $.36^{\mathrm{a}}$ \\
\hline Single/windowed & $32(45)$ & $18(37)$ & & \\
\hline Married/in a relationship & $39(55)$ & $31(63)$ & & \\
\hline Age, mean (SD) & $23.34(2.74)$ & $23.92(3.54)$ & $1.01(118)$ & $.31^{\mathrm{b}}$ \\
\hline
\end{tabular}

${ }^{\mathrm{a} C h i-s q u a r e ~ t e s t . ~}$

${ }^{\mathrm{b}}$ Independent $t$-test.

\section{Differences in Social Behaviors on Smartphone}

To examine differences in social behavior features between the nondepressed and depressed groups, we conducted 2-way ANOVA of depressive symptom (nondepressed group vs depressed group) $\times$ gender (male vs female). All social behavior features with significant results are shown in Table 3.

For "usage of traditional communication functions," 2 behavioral features had significant differences. Specifically, in terms of "receiving calls from contacts all day," the main effect of depressive symptom was significant $\left(F_{1,116}=3.995\right.$, $\left.P=.048, \eta^{2}=0.033\right)$. The frequency of receiving calls from contacts all day was significantly higher in the nondepressed group than in the depressed group $(P=.048)$. By contrast, the main effect of gender and the interaction effect of depressive symptom and gender were not significant $\left(F_{1,116}=0.005, P=.94\right.$, $\left.\eta^{2}=0.000 ; F_{1,116}=0.010, P=.92, \eta^{2}=0.000\right)$. As for "receiving calls from contacts in the afternoon," the main effect of depressive symptom was significant $\left(F_{1,116}=5.278, P=.02\right.$, $\left.\eta^{2}=0.044\right)$. The frequency of receiving calls from contacts in the afternoon was significantly higher in the nondepressed group than in the depressed group $(P=.02)$. However, the main effect of gender and the interaction effect of depressive symptom and gender were not significant $\left(F_{1,116}=0.004, P=.95, \eta^{2}=0.000\right.$; $\left.F_{1,116}=0.006, P=.94, \eta^{2}=0.000\right)$.

In "usage of social apps," 6 behavioral features had significant results. Specifically, in terms of "usage of social apps all day," the main effect of depressive symptom was significant $\left(F_{1,116}=6.801, P=.01, \eta^{2}=0.055\right)$. The frequency of usage of social apps was significantly higher in the depressed group than in the nondepressed group $(P=.01)$. By contrast, the main effect of gender and the interaction effect of depressive symptom and gender were not significant $\left(F_{1,116}=0.675, P=.41, \eta^{2}=0.006\right.$; $\left.F_{1,116}=1.654, P=.20, \eta^{2}=0.014\right)$. As for "usage of social apps in the evening," the main effect of depressive symptom was significant $\left(F_{1,116}=6.902, P=.01, \eta^{2}=0.056\right)$. People in the depressed group used social apps more frequently than people in the nondepressed group in the evening. However, the main effect of gender and the interaction effect of depressive symptom and gender were not significant $\left(F_{1,116}=0.095, P=.76, \eta^{2}=0.001\right.$; $\left.F_{1,116}=1.964, P=.16, \eta^{2}=0.017\right)$. 
Table 3. Differences in smartphone usage among participants with different depressive symptoms. ${ }^{\text {a }}$

\begin{tabular}{|c|c|c|c|c|c|c|c|c|c|c|}
\hline \multirow[t]{2}{*}{ Behavioral feature } & \multicolumn{2}{|c|}{$\begin{array}{l}\text { Nondepressed } \\
\text { group }\end{array}$} & \multicolumn{2}{|c|}{ Depressed group } & \multirow[t]{2}{*}{$\begin{array}{l}F_{\text {group }} \\
(d f)\end{array}$} & \multirow[t]{2}{*}{$\begin{array}{l}P_{\text {group }} \\
\text { value }\end{array}$} & \multirow[t]{2}{*}{$\begin{array}{l}F_{\text {gender }} \\
(d f)\end{array}$} & \multirow[t]{2}{*}{$\begin{array}{l}P_{\text {gender }} \\
\text { value }\end{array}$} & \multirow[t]{2}{*}{$\begin{array}{l}F_{\text {interac- }} \\
\text { tion }(d f)\end{array}$} & \multirow[t]{2}{*}{$\begin{array}{l}P_{\text {interac- }} \\
\text { tion value }\end{array}$} \\
\hline & Male & Female & Male & Female & & & & & & \\
\hline \multicolumn{11}{|l|}{$\begin{array}{l}\text { Traditional communication behavior, } \\
\text { mean (SD) }\end{array}$} \\
\hline Receiving calls from contacts all day & $\begin{array}{l}0.49 \\
(1.38)\end{array}$ & $\begin{array}{l}0.48 \\
(1.61)\end{array}$ & $\begin{array}{l}0.05 \\
(0.20)\end{array}$ & $\begin{array}{l}0.09 \\
(0.40)\end{array}$ & $\begin{array}{l}3.995 \\
(1,116)\end{array}$ & .048 & $\begin{array}{l}0.005 \\
(1,116)\end{array}$ & .94 & $\begin{array}{l}0.010 \\
(1,116)\end{array}$ & .92 \\
\hline $\begin{array}{l}\text { Receiving calls from contacts in the } \\
\text { afternoon }\end{array}$ & $\begin{array}{l}0.20 \\
(0.53)\end{array}$ & $\begin{array}{l}0.20 \\
(0.64)\end{array}$ & $\begin{array}{l}0.01 \\
(0.02)\end{array}$ & $\begin{array}{l}0.02 \\
(0.07)\end{array}$ & $\begin{array}{l}5.278 \\
(1,116)\end{array}$ & .02 & $\begin{array}{l}0.004 \\
(1,116)\end{array}$ & .95 & $\begin{array}{l}0.006 \\
(1,116)\end{array}$ & .94 \\
\hline \multicolumn{11}{|l|}{ Usage of social apps, mean (SD) } \\
\hline Usage of social apps all day & $\begin{array}{l}62.34 \\
(114.24)\end{array}$ & $\begin{array}{l}73.84 \\
(107.88)\end{array}$ & $\begin{array}{l}158.72 \\
(172.41)\end{array}$ & $\begin{array}{l}105.56 \\
(120.28)\end{array}$ & $\begin{array}{l}6.801 \\
(1,116)\end{array}$ & .01 & $\begin{array}{l}0.675 \\
(1,116)\end{array}$ & .41 & $\begin{array}{l}1.654 \\
(1,116)\end{array}$ & .20 \\
\hline Usage of social apps in the evening & $\begin{array}{l}26.30 \\
(40.08)\end{array}$ & $\begin{array}{l}42.61 \\
(69.62)\end{array}$ & $\begin{array}{l}86.42 \\
(115.56)\end{array}$ & $\begin{array}{l}60.90 \\
(88.05)\end{array}$ & $\begin{array}{l}6.902 \\
(1,116)\end{array}$ & .01 & $\begin{array}{l}0.095 \\
(1,116)\end{array}$ & .76 & $\begin{array}{l}1.964 \\
(1,116)\end{array}$ & .16 \\
\hline Usage of Weibo all day & $\begin{array}{l}6.64 \\
(14.79)\end{array}$ & $\begin{array}{l}6.31 \\
(14.79)\end{array}$ & $\begin{array}{l}6.34 \\
(13.08)\end{array}$ & $\begin{array}{l}25.49 \\
(34.78)\end{array}$ & $\begin{array}{l}6.689 \\
(1,116)\end{array}$ & .01 & $\begin{array}{l}6.642 \\
(1,116)\end{array}$ & .01 & $\begin{array}{l}7.118 \\
(1,116)\end{array}$ & .009 \\
\hline Usage of Weibo in the morning & $\begin{array}{l}1.46 \\
(3.27)\end{array}$ & $\begin{array}{l}1.23 \\
(2.90)\end{array}$ & $\begin{array}{l}1.94 \\
(4.40)\end{array}$ & $\begin{array}{l}6.11 \\
(8.58)\end{array}$ & $\begin{array}{l}8.838 \\
(1,116)\end{array}$ & .004 & $\begin{array}{l}4.765 \\
(1,116)\end{array}$ & .03 & $\begin{array}{l}5.932 \\
(1,116)\end{array}$ & .02 \\
\hline Usage of Weibo in the afternoon & $\begin{array}{l}1.88 \\
(4.59)\end{array}$ & $\begin{array}{l}2.11 \\
(5.57)\end{array}$ & $\begin{array}{l}1.58 \\
(3.17)\end{array}$ & $\begin{array}{l}8.19 \\
(10.81)\end{array}$ & $\begin{array}{l}6.370 \\
(1,116)\end{array}$ & .01 & $\begin{array}{l}8.918 \\
(1,116)\end{array}$ & .003 & $\begin{array}{l}7.764 \\
(1,116)\end{array}$ & .006 \\
\hline Usage of Weibo in the evening & $\begin{array}{l}3.30 \\
(7.40)\end{array}$ & $\begin{array}{l}2.97 \\
(6.73)\end{array}$ & $\begin{array}{l}2.82 \\
(5.97)\end{array}$ & $\begin{array}{l}11.19 \\
(17.93)\end{array}$ & $\begin{array}{l}4.531 \\
(1,116)\end{array}$ & .04 & $\begin{array}{l}4.889 \\
(1,116)\end{array}$ & .03 & $\begin{array}{l}5.731 \\
(1,116)\end{array}$ & .02 \\
\hline
\end{tabular}

${ }^{\text {a } D a t a}$ for descriptive statistics are the mean (SD) of the frequency of social behavior on smartphone. $F$ values of 2-way ANOVA are represented by $F_{\text {group }}, F_{\text {gender }}$, and $F_{\text {interaction }} P$ values of 2 -way ANOVA are represented by $P_{\text {group }}$ value, $P_{\text {gender }}$ value, and $P_{\text {interaction }}$ value.

In addition, Weibo was the only app with significant results among the 2 popular social apps. Under "usage of Weibo all day," the main effect of depressive symptom, the main effect of gender, and the interaction effect of depressive symptom and gender were significant $\left(F_{1,116}=6.689, P=.01, \eta^{2}=0.055\right.$; $F_{1,116}=6.642, P=.01, \eta^{2}=0.054 ; F_{1,116}=7.118, P=.009, \eta^{2}=0.058$, respectively). Simple effect analyses showed that in the depressed group, females used Weibo more frequently all day than males $\left(F_{1,116}=11.744, P=.001, \eta^{2}=0.092\right.$; Figure 1$)$. However, in the nondepressed group, there were no significant differences $\left(F_{1,116}=0.005, P=.94, \eta^{2}=0.000\right)$. As for "usage of Weibo in the morning," the main effect of depressive symptom, the main effect of gender, and the interaction effect of depressive symptom and gender were significant $\left(F_{1,116}=8.838, P=.004\right.$, $\eta^{2}=0.071 ; F_{1,116}=4.765, P=.03, \eta^{2}=0.039 ; F_{1,116}=5.932, P=.02$, $\eta^{2}=0.049$, respectively). Simple effect analyses showed that in the depressed group, the frequency of usage of Weibo among females in the morning was significantly higher than that of males $\left(F_{1,116}=9.105, P=.003, \eta^{2}=0.073\right.$; Figure 1$)$. However, in the nondepressed group, no significant gender differences existed $\left(F_{1,116}=0.039, P=.85, \eta^{2}=0.000\right)$.
Concerning "usage of Weibo in the afternoon," the main effect of depressive symptom, the main effect of gender, and the interaction effect of depressive symptom and gender were significant $\quad\left(F_{1,116}=6.370, \quad P=.01, \quad \eta^{2}=0.052 ; \quad F_{1,116}=8.918\right.$, $P=.003, \quad \eta^{2}=0.071 ; \quad F_{1,116}=7.764, \quad P=.006, \quad \eta^{2}=0.063$, respectively). Simple effect analyses showed that in the depressed group, females used Weibo more frequently in the afternoon than males $\left(F_{1,116}=14.224, P<.001, \eta^{2}=0.109\right.$; Figure 1). However, in the nondepressed group, no significant gender differences existed $\left(F_{1,116}=0.024, P=.88, \eta^{2}=0.000\right)$. In terms of "usage of Weibo in the evening," the main effect of gender and the interaction effect of depressive symptom and gender were not significant $\left(F_{1,116}=4.531, \quad P=.04, \quad \eta^{2}=0.038\right.$; $F_{1,116}=4.889, P=.03, \eta^{2}=0.040 ; F_{1,116}=5.731, P=.02, \eta^{2}=0.047$, respectively). Simple effect analyses showed that in the depressed group, females used Weibo more frequently than males in the evening $\left(F_{1,116}=9.052, P=.003, \eta^{2}=0.072\right.$; Figure $1)$. However, in the nondepressed group, no significant gender differences existed $\left(F_{1,116}=.020, P=.89, \eta^{2}=0.000\right)$. 
Figure 1. Interactions between depressive symptom and gender on usage of Weibo in different periods.
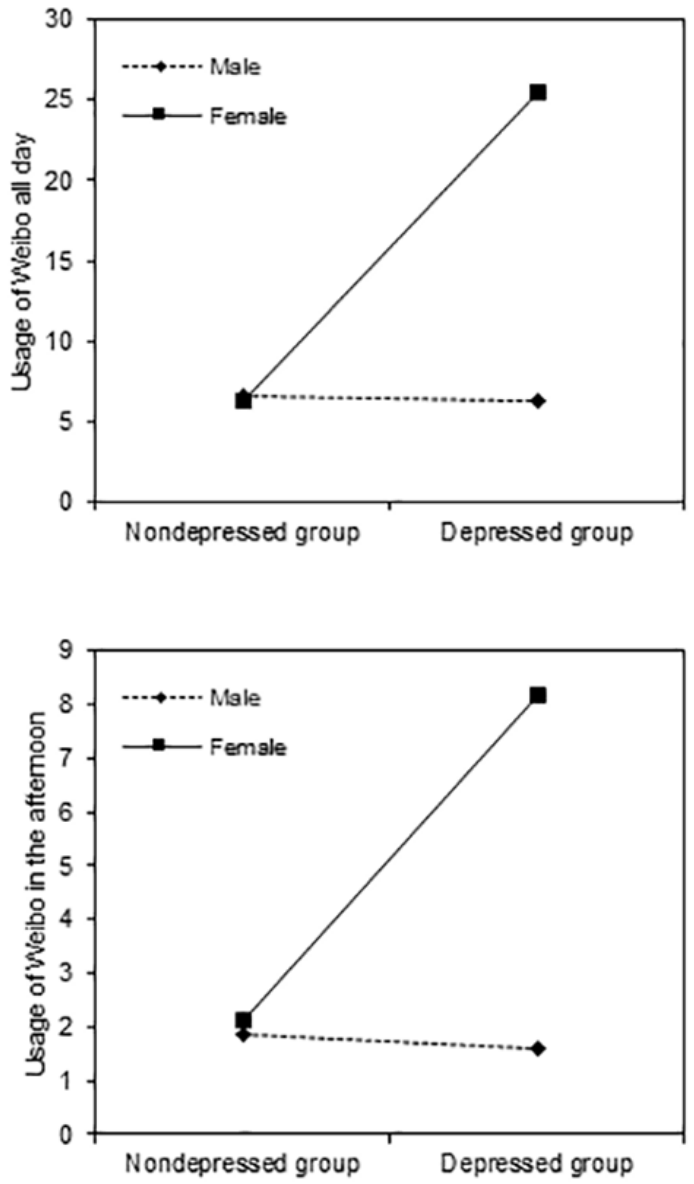

\section{Predictors of Depressive Symptoms}

The following 11 variables were entered into the multiple logistic regression model: "receiving calls from contacts all day," "receiving calls from contacts in the afternoon," "receiving calls from contacts in the evening," "usage of social apps all day," "usage of social apps in the morning," "usage of social apps in the evening," "usage of Weibo all day," "usage of Weibo in the morning," "usage of Weibo in the afternoon," "usage of
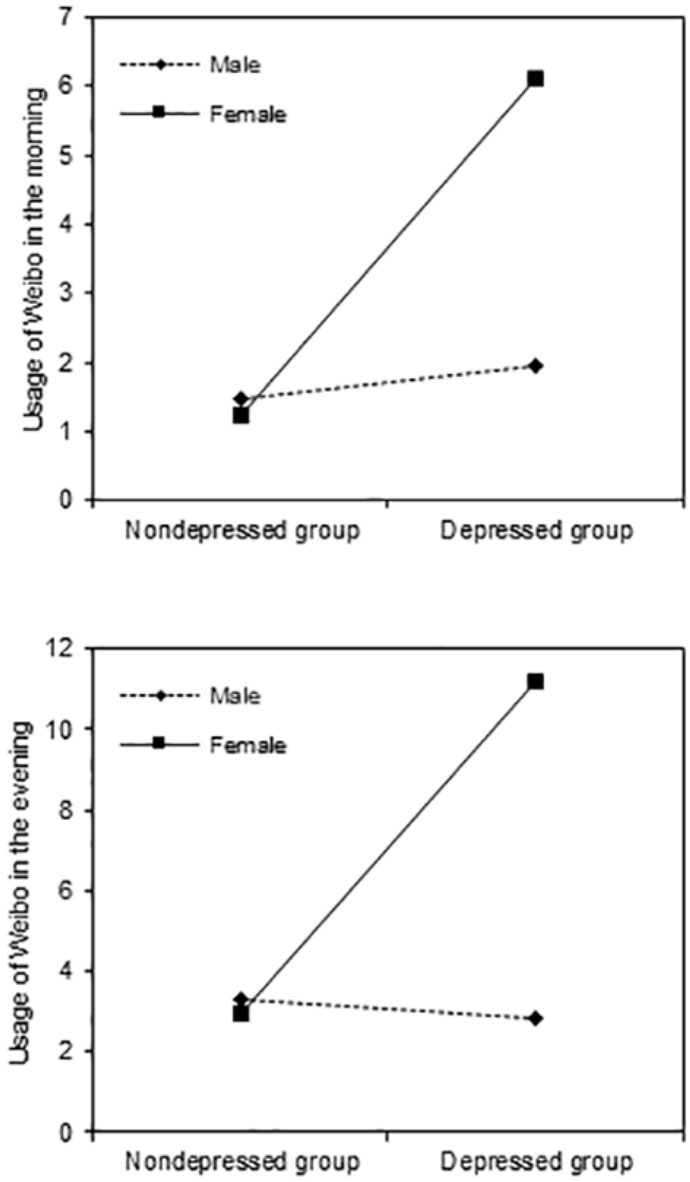

Weibo in the evening," and "usage of WeChat in the evening." Of the 11 variables, "usage of social apps in the evening" remained a significant independent predictor $(P=.02)$ of depressive symptoms in the model established on the whole sample (Table 4). In addition, "usage of social apps in the evening" emerged as a significant factor for male $(P=.01)$, and "usage of Weibo in the morning" emerged as a significant factor for female $(P=.03)$.

Table 4. Multiple logistic models of depressive symptoms.

\begin{tabular}{lll}
\hline Behavioral feature & Odds ratio $(95 \% \mathrm{CI})$ & $P$ value \\
\hline Total & $1.089(0.996-1.191)$ & .06 \\
$\quad$ Usage of Weibo in the morning & $1.007(1.001-1.013)$ & .02 \\
$\quad$ Usage of social apps in the evening & $0.032(0.000-2.705)$ & .13 \\
$\quad$ Receiving calls from contacts in the afternoon & & .01 \\
Male & $1.013(1.003-1.022)$ \\
$\quad$ Usage of social apps in the evening & \\
Female & $1.183(1.015-1.378)$ \\
$\quad$ Usage of Weibo in the morning
\end{tabular}




\section{Discussion}

\section{Principal Findings}

Our results supported the hypothesis that nondepressed and depressed users have differences in social behaviors on smartphones, and there were gender differences in social behavior among depressed users. Specifically, we used MobileSens to obtain metadata of smartphone usage on 120 participants, and extracted social behavior features to investigate the social behavior of nondepressed and depressed users. The results found depressed users received less calls from contacts (all day, in the afternoon) and used social apps more frequently (all day, in the evening) than nondepressed users. In the depressed group, females used Weibo more frequently than males (all day, in the morning, in the afternoon, in the evening).

\section{Traditional Communication Behavior of Depressed Users}

The results show that depressed users receive fewer calls from contacts throughout the day than nondepressed users. Consistent with our results, a cross-sectional study involving 6105 adults aged 18-84 years found that low frequency of contacts with friends and parents was a significant factor associated with depression [62]. In particular, social interactions with strong ties (eg, family, friends) play an important role in satisfying people's need for social connectedness [63-66]. Furthermore, meta-analyses have also shown that interventions for depression by addressing social relationships, including couples therapy and peer support, may be effective in reducing depressive symptoms [67,68]. Therefore, it is plausible that social interactions with strong ties via calls can satisfy psychological needs essential for reduction of depression and human flourishing. In addition, the result can be supplemented by one of the major assumptions of the behavioral theory of depression, namely, that a low rate of response-contingent positive reinforcement acts as an eliciting stimulus for depression [69-71]. Response-contingent positive reinforcement is defined as pleasurable or positive outcomes that follow an individual's behavior within his or her environment and increase the likelihood of those behaviors. Under such an assumption, social interactions with friends through calls could be perceived as a positive response contingent, whereas lack of social interaction with friends or family will increase depression.

Notably, only in the afternoon did the 2 groups differ significantly in the frequency of calls received from contacts over all periods $(P=.02)$. Previous studies have found a circadian rhythm of positive affect in healthy individuals, peaking in the afternoon [72,73]. Moreover, this positive affect was positively related to the number of interactions in which participants engaged, and the amount of time spent engaged in social contact [74]. According to the social enhancement model [75], those who already have good mental state enjoy more benefits from social interactions, while problems are only compounded for those who have psychological deficits. Thus, people who are already in good mental states have more willingness to engage in social interactions, which may encourage others to call them. However, unlike healthy individuals, the diurnal variation of positive affect in depressed patients showed an inverse-U shape with a steeper overall increase from morning lows to evening highs [76]. Thus, it is not surprising that difference exists in the number of receiving calls in the afternoon between the 2 groups.

\section{Usage of Social Apps of Depressed Users}

We found that depressed users use social apps throughout the day more frequently than nondepressed ones. There might be several reasons. First, depressed people expect that interpersonal interaction via the internet can alleviate their psychological problems, because they believe that it is less risky and easier to get support and build relationships online than face to face [77,78]. Given that $99.1 \%$ of internet users are mobile internet users in China [41], the positive association between depression and internet overuse would be replicated for a smartphone. Second, deficiency in self-regulation is a common manifestation among those with depression [79], which makes it difficult for them to maintain a healthy level and amount of smartphone use. Therefore, depressed users use social apps more frequently than nondepressed ones.

As for "usage of social apps in the evening," we found that it is a predictor for depression on both the overall data (all participants) and male data (male participants), and the usage frequency of depressed users is higher than nondepressed ones. Previous studies have found that depression symptoms tend to be relatively more active during the evening and night [59,80-82], which may exacerbate the usage of social apps. Additionally, people prefer to spend time on social media rather than face-to-face activities [83-85], but the quality of communication over social media has been highlighted as a potential limiting factor in building strong, emotionally intense relationships [86-88]. Furthermore, frequent smartphone usage can make people vulnerable to negative outcomes, such as interpersonal isolation [89]. Therefore, the usage of social apps not only fails to lessen their negative emotions, but also actually worsens these outcomes.

In the usage of top 2 social apps, at any time, the depressed ones used Weibo more frequently than the nondepressed ones. In the depressed group, females used Weibo more frequently than males. As we discussed above, the depressed ones use social apps more than the nondepressed ones, so this conclusion applies equally to Weibo. What deserves our attention is the gender differences in Weibo usage in the depressed group. Similar to Twitter, but unlike WeChat, Weibo focuses on sharing of opinions and information exchange rather than on social interaction [90], and offers some anonymity in online communication [91]. A previous study found that females are more likely to report Weibo usage for communicating with peers, passing time, and entertainment, whereas male users are more likely than females to report Weibo use for social compensation and social identity gratifications [92]. So depressed females are more likely to overuse Weibo than depressed males. Given a worsening of symptoms in the morning hours and early morning waking are characteristics of depression [58], depressed females may try to eliminate psychological problems by using Weibo. This could explain the usage of Weibo in the morning, which could serve as a predictor of depression in females. 


\section{Limitations and Future Work}

One limitation of this study is that we only use questionnaire-based scales to measure depression. Although the validity of the questionnaires as a screening tool in accessing depression severity has been well proven in the literature, the questionnaire score itself cannot be used as diagnostic. Second, the sample in this study was composed of healthy individuals rather than clinical patients, which means that there were few "real" patients with depression disorders in our sample. So our results are applicable to individuals with minor depression, and their applicability to patients with confirmed moderate to severe depression has not been verified. Moreover, given the convenience sampling method of this study and the majority of participants were students, the extent to which sampling bias affected the results cannot be determined. Therefore, replication and extension of this research using larger, more representative samples are desirable in future work.

Although the results found that depressed users used social apps more frequently than nondepressed ones, the psychological mechanism behind it is still unclear. For instance, because deficiency in self-regulation is a common manifestation among those with depression [79], future work could explore the mediating effect of self-regulation in the relationship between depression and social behavior on smartphones. Additionally, our results showed that compared with nondepressed users, depressed users received fewer calls from acquaintances. Future studies may need to pay closer attention to whether it is the reason that depressed users use social apps frequently. Furthermore, our result found gender differences in some social behaviors among depressed users (eg, the usage of Weibo), which suggests that social-based features should be treated as a personalized feature that should be assessed in a within-subject analysis in future studies.

\section{Conclusions}

In summary, by analyzing metadata of smartphone usage acquired by MobileSens, we found that relationships exist between depression and social behavior on smartphones, which means we may be able to implement an early diagnosis system of depression through smartphone usage. Besides, the results of this study provide useful suggestions to those who are depressive in daily lives.

\section{Acknowledgments}

This study was partially supported by the Key Research Program of the Chinese Academy of Sciences (No. ZDRW-XH-2019-4). The authors thank everyone who participated in the study.

\section{Conflicts of Interest}

None declared.

\section{References}

1. Friedrich M. Depression Is the Leading Cause of Disability Around the World. JAMA 2017 Apr 18;317(15):1517. [doi: 10.1001/jama.2017.3826] [Medline: 28418490]

2. Lewinsohn PM, Solomon A, Seeley JR, Zeiss A. Clinical implications of "subthreshold" depressive symptoms. J Abnorm Psychol 2000 May;109(2):345-351. [Medline: 10895574]

3. Ruo B, Rumsfeld JS, Hlatky MA, Liu H, Browner WS, Whooley MA. Depressive symptoms and health-related quality of life: the Heart and Soul Study. JAMA 2003 Jul 09;290(2):215-221 [FREE Full text] [doi: 10.1001/jama.290.2.215] [Medline: $\underline{12851276]}$

4. Lerner D, Henke RM. What does research tell us about depression, job performance, and work productivity? J Occup Environ Med 2008 Apr;50(4):401-410. [doi: 10.1097/JOM.0b013e31816bae50] [Medline: 18404013]

5. Musselman DL, Evans DL, Nemeroff CB. The relationship of depression to cardiovascular disease: epidemiology, biology, and treatment. Arch Gen Psychiatry 1998 Jul 01;55(7):580-592. [doi: 10.1001/archpsyc.55.7.580] [Medline: 9672048]

6. Wragg RE, Jeste DV. Overview of depression and psychosis in Alzheimer's disease. Am J Psychiatry 1989 May;146(5):577-587. [doi: 10.1176/ajp.146.5.577] [Medline: 2653053]

7. Minkoff K, Bergman E, Beck AT, Beck R. Hopelessness, depression, and attempted suicide. Am J Psychiatry 1973 Apr;130(4):455-459. [doi: 10.1176/ajp.130.4.455] [Medline: 4691303]

8. Hawton K, Casañas ICC, Haw C, Saunders K. Risk factors for suicide in individuals with depression: a systematic review. J Affect Disord 2013 May;147(1-3):17-28. [doi: 10.1016/j.jad.2013.01.004] [Medline: 23411024]

9. Mathers CD, Loncar D. Projections of global mortality and burden of disease from 2002 to 2030. PLoS Med 2006 Nov;3(11):e442 [FREE Full text] [doi: 10.1371/journal.pmed.0030442] [Medline: 17132052]

10. Young AS, Klap R, Sherbourne CD, Wells KB. The quality of care for depressive and anxiety disorders in the United States. Arch Gen Psychiatry 2001 Jan 01;58(1):55-61. [doi: 10.1001/archpsyc.58.1.55] [Medline: 11146758]

11. Harman JS, Edlund MJ, Fortney JC. Disparities in the adequacy of depression treatment in the United States. Psychiatr Serv 2004 Dec;55(12):1379-1385. [doi: 10.1176/appi.ps.55.12.1379] [Medline: 15572565]

12. Simon G, VonKorff M. Recognition, management, and outcomes of depression in primary care. Arch Fam Med 1995 Feb;4(2):99-105. [doi: 10.1001/archfami.4.2.99] [Medline: 7842160]

13. van Weel C, van Weel-Baumgarten E, van Rijswijk E. Treatment of depression in primary care. BMJ 2009 Mar 19;338(mar19 1):b934. [doi: 10.1136/bmj.b934] [Medline: 19299476] 
14. Schulberg HC, Saul M, McClelland M, Ganguli M, Christy W, Frank R. Assessing depression in primary medical and psychiatric practices. Arch Gen Psychiatry 1985 Dec 01;42(12):1164-1170. [doi: 10.1001/archpsyc.1985.01790350038008] [Medline: 4074109]

15. Wells KB, Hays RD, Burnam MA, Rogers W, Greenfield S, Ware JE. Detection of depressive disorder for patients receiving prepaid or fee-for-service care. Results from the Medical Outcomes Study. JAMA 1989 Dec 15;262(23):3298-3302. [doi: 10.1001/jama.262.23.3298] [Medline: 2585674]

16. Kamphuis MH, Stegenga BT, Zuithoff NPA, King M, Nazareth I, de Wit NJ, et al. Does recognition of depression in primary care affect outcome? The PREDICT-NL study. Fam Pract 2012 Feb 22;29(1):16-23. [doi: 10.1093/fampra/cmr049] [Medline: 21859837]

17. Kemp S. DIGITAL 2019: Global Internet Use Accelerates. 2019 Jan. URL: https://wearesocial.com/blog/2019/01/ digital-2019-global-internet-use-accelerates [accessed 2020-03-01]

18. Kim M, Kim H, Kim K, Ju S, Choi J, Mi Y. Smartphone Addiction: (Focused Depression, Aggression and Impulsion) among College Students. Indian Journal of Science and Technology 2015;8(25):1-8 [FREE Full text] [doi: 10.17485/ijst/2015/v8i25/80215]

19. Matar Boumosleh J, Jaalouk D. Depression, anxiety, and smartphone addiction in university students- A cross sectional study. PLoS One 2017 Aug 4;12(8):e0182239 [FREE Full text] [doi: 10.1371/journal.pone.0182239] [Medline: 28777828]

20. Demirci K, Akgönül M, Akpinar A. Relationship of smartphone use severity with sleep quality, depression, and anxiety in university students. J Behav Addict 2015 Jun;4(2):85-92 [FREE Full text] [doi: 10.1556/2006.4.2015.010] [Medline: 26132913]

21. Yang J, Fu X, Liao X, Li Y. Association of problematic smartphone use with poor sleep quality, depression, and anxiety: A systematic review and meta-analysis. Psychiatry Res 2020 Feb;284:112686. [doi: 10.1016/j.psychres.2019.112686] [Medline: 31757638 ]

22. Kim J, Seo M, David P. Alleviating depression only to become problematic mobile phone users: Can face-to-face communication be the antidote? Computers in Human Behavior 2015 Oct;51:440-447. [doi: 10.1016/j.chb.2015.05.030]

23. Alter A. Irresistible: The Rise of Addictive Technology and the Business of Keeping Us Hooked. London, England: Penguin; 2017.

24. Misra S, Cheng L, Genevie J, Yuan M. The iPhone Effect: The Quality of In-Person Social Interactions in the Presence of Mobile Devices. Environment and Behavior 2014 Jul;48(2):275-298. [doi: 10.1177/0013916514539755]

25. Przybylski AK, Weinstein N. A Large-Scale Test of the Goldilocks Hypothesis. Psychol Sci 2017 Feb;28(2):204-215. [doi: 10.1177/0956797616678438] [Medline: 28085574]

26. Razavi R, Gharipour A, Gharipour M. Depression screening using mobile phone usage metadata: a machine learning approach. J Am Med Inform Assoc 2020 Apr 01;27(4):522-530. [doi: 10.1093/jamia/ocz221] [Medline: 31977041]

27. Višnjić A, Veličković V, Sokolović D, Stanković M, Mijatović K, Stojanović M, et al. Relationship between the Manner of Mobile Phone Use and Depression, Anxiety, and Stress in University Students. Int J Environ Res Public Health 2018 Apr 08;15(4):697 [FREE Full text] [doi: 10.3390/ijerph15040697] [Medline: 29642471]

28. Thomée S, Dellve L, Härenstam A, Hagberg M. Perceived connections between information and communication technology use and mental symptoms among young adults - a qualitative study. BMC Public Health 2010 Feb 12;10(1):66 [FREE Full text] [doi: 10.1186/1471-2458-10-66] [Medline: 20152023]

29. Tamura H, Nishida T, Tsuji A, Sakakibara H. Association between Excessive Use of Mobile Phone and Insomnia and Depression among Japanese Adolescents. Int J Environ Res Public Health 2017 Jun 29;14(7):701 [FREE Full text] [doi: 10.3390/ijerph14070701] [Medline: 28661428]

30. Boase J, Ling R. Measuring Mobile Phone Use: Self-Report Versus Log Data. J Comput-Mediat Comm 2013 Jun 10;18(4):508-519. [doi: 10.1111/jcc4.12021]

31. Kobayashi T, Boase J. No Such Effect? The Implications of Measurement Error in Self-Report Measures of Mobile Communication Use. Communication Methods and Measures 2012 Apr;6(2):126-143. [doi: 10.1080/19312458.2012.679243]

32. Cornet VP, Holden RJ. Systematic review of smartphone-based passive sensing for health and wellbeing. J Biomed Inform 2018 Jan;77:120-132 [FREE Full text] [doi: 10.1016/j.jbi.2017.12.008] [Medline: 29248628]

33. Ben-Zeev D, Scherer EA, Wang R, Xie H, Campbell AT. Next-generation psychiatric assessment: Using smartphone sensors to monitor behavior and mental health. Psychiatr Rehabil J 2015 Sep;38(3):218-226 [FREE Full text] [doi: 10.1037/prj0000130] [Medline: 25844912]

34. Rohani DA, Faurholt-Jepsen M, Kessing LV, Bardram JE. Correlations Between Objective Behavioral Features Collected From Mobile and Wearable Devices and Depressive Mood Symptoms in Patients With Affective Disorders: Systematic Review. JMIR Mhealth Uhealth 2018 Aug 13;6(8):e165 [FREE Full text] [doi: 10.2196/mhealth.9691] [Medline: 30104184 ]

35. Saeb S, Zhang M, Karr CJ, Schueller SM, Corden ME, Kording KP, et al. Mobile Phone Sensor Correlates of Depressive Symptom Severity in Daily-Life Behavior: An Exploratory Study. J Med Internet Res 2015 Jul 15;17(7):e175 [FREE Full text] [doi: 10.2196/jmir.4273] [Medline: 26180009]

36. Faurholt-Jepsen M, Vinberg M, Frost M, Debel S, Margrethe Christensen E, Bardram JE, et al. Behavioral activities collected through smartphones and the association with illness activity in bipolar disorder. Int J Methods Psychiatr Res 2016 Dec 01;25(4):309-323 [FREE Full text] [doi: 10.1002/mpr.1502] [Medline: 27038019] 
37. Canzian L, Musolesi M. Trajectories of depression: unobtrusive monitoring of depressive states by means of smartphone mobility traces analysis. New York, NY: Association for Computing Machinery; 2015 Sep Presented at: The 2015 ACM International Joint Conference on Pervasive and Ubiquitous Computing; September 2015; Osaka, Japan. [doi: $10.1145 / 2750858.2805845]$

38. Abdullah S, Matthews M, Frank E, Doherty G, Gay G, Choudhury T. Automatic detection of social rhythms in bipolar disorder. J Am Med Inform Assoc 2016 May;23(3):538-543. [doi: 10.1093/jamia/ocv200] [Medline: 26977102]

39. Burns MN, Begale M, Duffecy J, Gergle D, Karr CJ, Giangrande E, et al. Harnessing context sensing to develop a mobile intervention for depression. J Med Internet Res 2011 Aug 12;13(3):e55 [FREE Full text] [doi: 10.2196/jmir.1838] [Medline: 21840837]

40. Baker DA, Algorta GP. The Relationship Between Online Social Networking and Depression: A Systematic Review of Quantitative Studies. Cyberpsychol Behav Soc Netw 2016 Nov;19(11):638-648. [doi: 10.1089/cyber.2016.0206] [Medline: 27732062]

41. China Internet Network Information Center. The 44th China Statistical Report on Internet Development Dictionary. 2019 Aug. URL: http://www.cac.gov.cn/2019-08/30/c 1124938750.htm [accessed 2020-03-01]

42. Bebbington P, Brugha T, Meltzer H, Farrell M, Ceresa C, Jenkins R, et al. Psychiatric disorder and dysfunction in the UK National Survey of Psychiatric Morbidity. Soc Psychiatry Psychiatr Epidemiol 2000 May 16;35(5):191-197. [doi: 10.1007/s001270050227] [Medline: 10941993]

43. Wilhelm K, Parker G, Asghari A. Sex differences in the experience of depressed mood state over fifteen years. Soc Psychiatry Psychiatr Epidemiol 1998 Jan 9;33(1):16-20. [doi: 10.1007/s001270050016] [Medline: 9448440]

44. Bianchi A, Phillips JG. Psychological predictors of problem mobile phone use. Cyberpsychol Behav 2005 Feb;8(1):39-51. [doi: $10.1089 / \mathrm{cpb} .2005 .8 .39]$ [Medline: 15738692$]$

45. Toda M, Monden K, Kubo K, Morimoto K. MOBILE PHONE DEPENDENCE AND HEALTH-RELATED LIFESTYLE OF UNIVERSITY STUDENTS. Soc Behav Pers 2006 Jan 01;34(10):1277-1284. [doi: 10.2224/sbp.2006.34.10.1277]

46. Billieux J, Van der Linden M, Rochat L. The role of impulsivity in actual and problematic use of the mobile phone. Appl. Cognit. Psychol 2008 Dec;22(9):1195-1210. [doi: 10.1002/acp.1429]

47. Igarashi T, Takai J, Yoshida T. Gender differences in social network development via mobile phone text messages: A longitudinal study. Journal of Social and Personal Relationships 2016 Jun 30;22(5):691-713. [doi: $10.1177 / 0265407505056492]$

48. Jenaro C, Flores N, Gómez-Vela M, González-Gil F, Caballo C. Problematic internet and cell-phone use: Psychological, behavioral, and health correlates. Addiction Research \& Theory 2009 Jul 11;15(3):309-320. [doi: 10.1080/16066350701350247]

49. Sánchez-Martínez M, Otero A. Factors associated with cell phone use in adolescents in the community of Madrid (Spain). Cyberpsychol Behav 2009 Apr;12(2):131-137. [doi: 10.1089/cpb.2008.0164] [Medline: 19072078]

50. Guo R, Zhu T, Wang Y, Xu X. MobileSens: A framework of behavior logger on Andriod mobile device. New York, NY: IEEE; 2011 Presented at: 2011 6th International Conference on Pervasive Computing and Applications; October 2011; Port Elizabeth, South Africa p. 281-286. [doi: 10.1109/ICPCA.2011.6106518]

51. Li A, Li H, Guo R, Zhu T. MobileSens: a ubiquitous psychological laboratory based on mobile device. International Journal of Cyber Behavior, Psychology and Learning (IJCBPL) 2013;3(2):47-55. [doi: 10.4018/ijcbpl.2013040104]

52. Radloff LS. The CES-D Scale: A Self-Report Depression Scale for Research in the General Population. Applied Psychological Measurement 2016 Jul 26;1(3):385-401. [doi: 10.1177/014662167700100306]

53. Roberts RE. Reliability of the CES-D scale in different ethnic contexts. Psychiatry Research 1980 May;2(2):125-134. [doi: 10.1016/0165-1781(80)90069-4]

54. Jie Z, Zhen-Yun W, Ge F, Juan L, Bu-Xin H, Zhi-Yan C. Development of the Chinesr age norms of CES-D in urban area. Chinese Mental Health Journal 2010 Apr 13;24(2):139-143. [doi: 10.3969/j.issn.1000-6729.2010.02.015]

55. Salgado-Delgado R, Tapia Osorio A, Saderi N, Escobar C. Disruption of circadian rhythms: a crucial factor in the etiology of depression. Depress Res Treat 2011;2011:839743 [FREE Full text] [doi: 10.1155/2011/839743] [Medline: 21845223]

56. Germain A, Kupfer DJ. Circadian rhythm disturbances in depression. Hum Psychopharmacol 2008 Oct;23(7):571-585 [FREE Full text] [doi: 10.1002/hup.964] [Medline: 18680211]

57. Goodwin F, Jamison K. Manic-Depressive Illness: Bipolar Disorders and Recurrent Depression, Second Edition. Oxford, UK: Oxford University Press; 2007.

58. Battle DE. Diagnostic and Statistical Manual of Mental Disorders (DSM). Codas 2013;25(2):191-192 [FREE Full text] [doi: 10.1590/s2317-17822013000200017] [Medline: 24413388]

59. Gordijn M, Beersma D, Bouhuys A, Reinink E, Van den Hoofdakker R. A longitudinal study of diurnal mood variation in depression; characteristics and significance. Journal of Affective Disorders 1994 Aug;31(4):261-273. [doi: 10.1016/0165-0327(94)90102-3]

60. Zich JM, Attkisson CC, Greenfield TK. Screening for depression in primary care clinics: the CES-D and the BDI. Int J Psychiatry Med 1990;20(3):259-277. [doi: 10.2190/LYKR-7VHP-YJEM-MKM2] [Medline: 2265888]

61. Ranganathan P, Pramesh CS, Aggarwal R. Common pitfalls in statistical analysis: Logistic regression. Perspect Clin Res 2017;8(3):148-151 [FREE Full text] [doi: 10.4103/picr.PICR 87 17] [Medline: 28828311] 
62. Kleinberg A, Aluoja A, Vasar V. Social support in depression: structural and functional factors, perceived control and help-seeking. Epidemiol Psychiatr Sci 2013 Sep 24;22(4):345-353. [doi: 10.1017/s2045796013000504]

63. Mehl MR, Vazire S, Holleran SE, Clark CS. Eavesdropping on happiness: well-being is related to having less small talk and more substantive conversations. Psychol Sci 2010 Apr 18;21(4):539-541 [FREE Full text] [doi: 10.1177/0956797610362675] [Medline: 20424097]

64. Reis HT, Sheldon KM, Gable SL, Roscoe J, Ryan RM. Daily Well-Being: The Role of Autonomy, Competence, and Relatedness. Pers Soc Psychol Bull 2016 Jul 02;26(4):419-435. [doi: 10.1177/0146167200266002]

65. Vittengl JR, Holt CS. Positive and Negative Affect in Social Interactions as a Function of Partner Familiarity, Quality of Communication, and Social Anxiety. Journal of Social and Clinical Psychology 1998 Jun;17(2):196-208. [doi: 10.1521/jscp.1998.17.2.196]

66. Wheeler L, Reis H, Nezlek J. Loneliness, social interaction, and sex roles. J Pers Soc Psychol 1983 Oct;45(4):943-953. [doi: 10.1037//0022-3514.45.4.943] [Medline: 6631669]

67. Pfeiffer PN, Heisler M, Piette JD, Rogers MA, Valenstein M. Efficacy of peer support interventions for depression: a meta-analysis. Gen Hosp Psychiatry 2011 Jan;33(1):29-36 [FREE Full text] [doi: 10.1016/j.genhosppsych.2010.10.002] [Medline: 21353125]

68. Barbato A, D'Avanzo B. Efficacy of couple therapy as a treatment for depression: a meta-analysis. Psychiatr Q 2008 Jun 8;79(2):121-132. [doi: 10.1007/s11126-008-9068-0] [Medline: 18259866 ]

69. Lewinsohn P. A Behavioral Approach to Depression: Essential Papers on Depression. Manhattan, NY: NYU Press; 1974:150-172.

70. Lewinsohn PM, Graf M. Pleasant activities and depression. J Consult Clin Psychol 1973 Oct;41(2):261-268. [doi: 10.1037/h0035142] [Medline: 4147832]

71. Lewinsohn PM, Libet J. Pleasant events, activity schedules, and depressions. J Abnorm Psychol 1972 Jun;79(3):291-295. [doi: 10.1037/h0033207] [Medline: 5033370]

72. Boivin DB, Czeisler CA, Dijk DJ, Duffy JF, Folkard S, Minors DS, et al. Complex interaction of the sleep-wake cycle and circadian phase modulates mood in healthy subjects. Arch Gen Psychiatry 1997 Feb 01;54(2):145-152. [doi: 10.1001/archpsyc.1997.01830140055010] [Medline: 9040282]

73. Murray G, Nicholas CL, Kleiman J, Dwyer R, Carrington MJ, Allen NB, et al. Nature's clocks and human mood: the circadian system modulates reward motivation. Emotion 2009 Oct;9(5):705-716. [doi: 10.1037/a0017080] [Medline: 19803592]

74. Berry DS, Hansen JS. Positive affect, negative affect, and social interaction. Journal of Personality and Social Psychology 1996 Oct;71(4):796-809. [doi: 10.1037/0022-3514.71.4.796]

75. Kraut R, Kiesler S, Boneva B, Cummings J, Helgeson V, Crawford A. Internet Paradox Revisited. J Social Isssues 2002 Jan;58(1):49-74. [doi: 10.1111/1540-4560.00248]

76. Crowe E, Daly M, Delaney L, Carroll S, Malone KM. The intra-day dynamics of affect, self-esteem, tiredness, and suicidality in Major Depression. Psychiatry Res 2019 Sep;279:98-108. [doi: 10.1016/j.psychres.2018.02.032] [Medline: 29661498]

77. Morahan-Martin J. Internet use and abuse and psychological problems. In: Adam J, Katelyn M, Tom P, Ulf-Dietrich R, editors. Oxford Handbook of Internet Psychology. Oxford, UK: Oxford University Press; 2007.

78. Morahan-Martin J, Schumacher P. Incidence and correlates of pathological Internet use among college students. Computers in Human Behavior 2000 Jan;16(1):13-29. [doi: 10.1016/s0747-5632(99)00049-7]

79. Bandura A, Pastorelli C, Barbaranelli C, Caprara GV. Self-efficacy pathways to childhood depression. Journal of Personality and Social Psychology 1999;76(2):258-269. [doi: 10.1037/0022-3514.76.2.258]

80. Rusting CL, Larsen RJ. Diurnal patterns of unpleasant mood: associations with neuroticism, depression, and anxiety. J Pers 1998 Feb 28;66(1):85-103. [doi: 10.1111/1467-6494.00004] [Medline: 9457771]

81. Lustberg L, Reynolds CF. Depression and insomnia: questions of cause and effect. Sleep Med Rev 2000 Jun;4(3):253-262. [doi: 10.1053/smrv.1999.0075] [Medline: 12531168 ]

82. Gellman M, Turner J. Encyclopedia of Behavioral Medicine. New York, NY: Springer; 2013.

83. NIE NH. Sociability, Interpersonal Relations, and the Internet. American Behavioral Scientist 2016 Jul 27;45(3):420-435. [doi: $10.1177 / 00027640121957277]$

84. Mesch GS. Family Relations and the Internet: Exploring a Family Boundaries Approach. Journal of Family Communication 2006 Apr;6(2):119-138. [doi: 10.1207/s15327698jfc0602 2]

85. Nie N, Hillygus D. The impact of Internet use on sociability: Time-diary findings. It \& Society 2002;1(1):1-20 [FREE Full text]

86. Schiffrin H, Edelman A, Falkenstern M, Stewart C. The associations among computer-mediated communication, relationships, and well-being. Cyberpsychol Behav Soc Netw 2010 Jun;13(3):299-306. [doi: 10.1089/cyber.2009.0173] [Medline: 20557249]

87. Cummings JN, Butler B, Kraut R. The quality of online social relationships. Commun. ACM 2002 Jul;45(7):103-108. [doi: $10.1145 / 514236.514242]$

88. Gross EF, Juvonen J, Gable SL. Internet Use and Well-Being in Adolescence. J Social Isssues 2002 Jan;58(1):75-90. [doi: $\underline{10.1111 / 1540-4560.00249}$ ] 
89. Turkle S. Reclaiming Conversation: The Power of Talk in the Digital Age. New York, NY: Penguin Press; Oct 6, 2015.

90. Kwak H, Lee C, Park H, Moon S. What is Twitter, a social network or a news media? In: Proceedings of the 19th International Conference on World Wide Web. New York, NY: Association for Computing Machinery; 2010 Apr Presented at: WWW '10: The 19th International Conference on World Wide Web; April 2010; Raleigh, NC p. 591-600. [doi: 10.1145/1772690.1772751]

91. Huberman BA, Romero DM, Wu F. Social Networks that Matter: Twitter Under the Microscope. arXiv 2008 [FREE Full text] [doi: 10.2139/ssrn.1313405]

92. Chan M, Wu X, Hao Y, Xi R, Jin T. Microblogging, online expression, and political efficacy among young chinese citizens: the moderating role of information and entertainment needs in the use of weibo. Cyberpsychol Behav Soc Netw 2012 Jul;15(7):345-349. [doi: 10.1089/cyber.2012.0109] [Medline: 22780993]

\author{
Abbreviations \\ CES-D: The Center for Epidemiological Studies-Depression Scale \\ OR: odds ratio

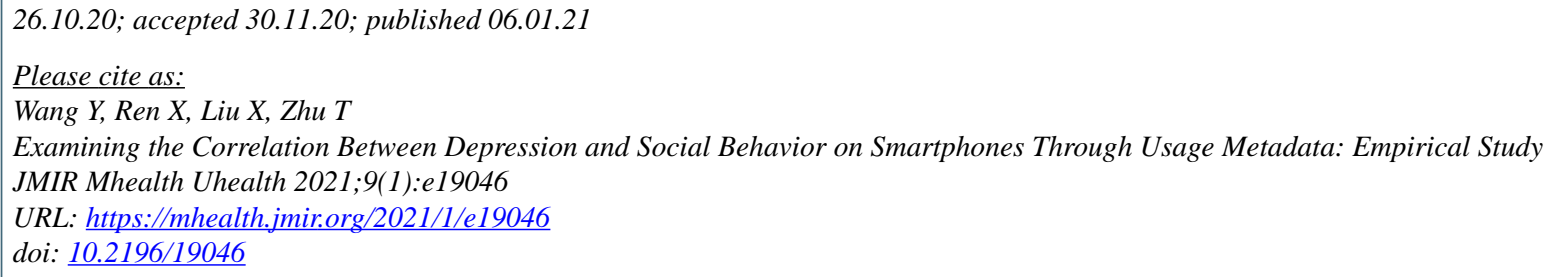

(C) Yameng Wang, Xiaotong Ren, Xiaoqian Liu, Tingshao Zhu. Originally published in JMIR mHealth and uHealth (http://mhealth.jmir.org), 06.01.2021. This is an open-access article distributed under the terms of the Creative Commons Attribution License (https://creativecommons.org/licenses/by/4.0/), which permits unrestricted use, distribution, and reproduction in any medium, provided the original work, first published in JMIR mHealth and uHealth, is properly cited. The complete bibliographic information, a link to the original publication on http://mhealth.jmir.org/, as well as this copyright and license information must be included. 